https://doi.org/10.31470/2706-7904-2020-15-12-15

\title{
LINGUO-COMMUNICATIVE DIMENSION OF CULTURAL DIVERSITY
}

\section{Лінгвокомунікаційний аспект культурного розмаїття}

\author{
Maria Abysova \\ Ph.D. in Philosophy, Associate Professor \\ National Aviation University (Ukraine) \\ maria.abysova@gmail.com \\ https://orcid.org/0000-0002-6461-7769

\section{Tetiana Shorina} \\ Ph.D. in Philosophy, Associate Professor \\ National Aviation University (Ukraine) \\ tetiana.shorina@npp.nau.edu.ua \\ https://orcid.org/0000-0001-9281-7840
}

\begin{abstract}
The article deal with the linguo-communicative analysis of the transformation of the national-civil society under the influence of multiculturalism as a comprehensive legitimation of the cultural plurality practice. The study is based on a hypothesis of the complex and ambiguous nature of the language and culture interactions. "Language-culture» relations encompasses all the layers of the language system, all functions of the language, which leads to the heterogeneity of linguistic units marked by a cultural component. In the modern society, in the «language-culture» relations, the the national-civil culture dominated, unambiguously affecting the language system. However, in the conditions of multiculturalism and the rupture of the national-civil system, traditions and norms of civil culture are weakened, the linguo-cultural balance is being violated, which becomes an open problem of the post-modern society.
\end{abstract}

Key words: linguo-communication, multiculturalism, national-civic culture.

\section{Introduction}

Multiculturalism is a versatile and multi aspect phenomenon. Multiculturalism is understood both as a political project, recognizing cultural differences, and as a model of a multicultural society. In particular, multiculturalism is viewed as a special pluralistic discourse served to emphasize the importance of integrating cultural differences, free 
expression of the interests and values of various socio-cultural groups. But all these approaches offer a descriptive model rather than an explanatory one, when it is important not only to state, but also to identify a fundamentally new situation in the position of the socio-cultural system of modern states. The subject of our research is the linguistic and communicative aspect. In the context of modern globalization, national and ethnic processes are taking place in contradictory tendencies: the global coexistence of ethnically diverse cultures and, at the same time, tendencies towards diversity of ethno-nationalism, national sovereignty. In such a contradiction, the role and importance of intercultural communication is extremely growing. It either leads to agreement or to the conflict situations in a multicultural environment.

\section{Methods and Techniques of the Research}

The methodological basis of the research is general scientific methodological provisions, theory of cultural linguistics, communication studies, intercultural communications; complex approach to the material: axiological, anthropocentric, cultural.

\section{Results}

Cultural diversity as a phenomenon and trend of sociocultural development has always been present in the officially homogeneous space of national and civil culture. There have always been peripheral or subordinate linguistic identities. However, these communities have never disputed the central position of national cultures and, moreover, usually sought to get closer to them, to reduce the differences separating them. Despite the reproduction of cultural differences, the basic model of the national-civil type of acculturation, that is, the choice of cultural identity and inclusion into a foreign culture, which for decades assimilation have served - the acceptance of the values and norms of the main culture, the unity of the nation as a moral community of equals. The principles, norms and possibilities of socio-cultural integration of society were reduced to this, in fact, no alternative variant of acculturation.

To promote the concept of «one state - one nation - one national language», to suppress the germs of ethno-nationalism and regionalism in many countries, one of the autochthonous languages is cultivated, with the help of which cultural and political unity and meta-ethnopolitical community are created. The need for a single normalized codified national language appears when ordinary citizens become an important component of the state. And the introduction of a standard language initially pursues exclusively pragmatic, not cultural goals: citizens must understand the government of their country. 
Language policy requires special flexibility and consideration of many factors in the conditions of multi-ethnic and multilingual countries, where the ratio of languages in terms of their communicative functions, in terms of their use in various spheres of social life is closely related to the mechanisms of political governance, national harmony and social stability. As a result, as history testifies, the dominant nation each time showed rejection of other languages. Associated with it there is the requirement, which is common for the ruling nation, that national minorities learn the language of the majority and use it everywhere in public life - while voting, in court, on concluding agreements, etc. Sometimes the language of a minority is recognized as a second state language, but more often it is used only at home, in church and in private schools (or it is slowly and painfully lost).

In some cases, the recognition of the language of a national minority living on the territory of a national state and the transfer of administrative functions to it, albeit to a very limited extent, is a solution to the conflict situation between the national majority and the national minority. The importance of the issue of the right to use the national language and, in general, the role of the national language is confirmed by the fact that this moment is taken into account when making normative documents at the world level. An example is the United Nations Convention on Civil and Political Rights (1966), which states, in particular, that members of minorities «cannot be denied the right to own, with others in their group, their own culture or use their own language» (Уолцер, 2000: 45).

As E. Hobsbawm writes, the creation of a university with teaching in the native language becomes a real triumph of linguistic emancipation as the privileged use of any language as the only language of instruction and culture in the country is associated with political and ideological considerations (Hobsbawm, 1997: 87).

The national language as an instrument of national identity is used by general education, which is the main institution that makes standardization and codification of the literary language. A special role is played by linguistic purism and the history of grammaticalization and lexicalization of linguistic units. The influence of the idea of language standardization on the language inventory (first of all, the dictionary) should be based not only on the data of the literary language, but also on dialects, professional argos, colloquial speech - i.e. for the entire section of language styles and layers of use, since verbal self-identification and language mastery play a decisive role in the formation of an individual sense of national belonging.

The triumph of the policy of multiculturalism has paradoxically turned against it itself, undermined confidence in the ability to quickly and effectively unite a multicultural society with its help on the basis of equality of cultures and the practice of providing additional rights and benefits depending on a person's belonging to a group. The discrepancy between the results of this policy and the very logic of multicultural practices 
and the foundations of socio-cultural unity of modern states - the institution of unitary citizenship, national-civil identity, loyalty to the state on the principle of a person's belonging to a national territory - was indicated.

The modern situation is characterized by a new character of linguo-cultural interaction of cultures. The matter is not in the very presence of a plurality of cultures, but in the fact that their linguo-cultural reproduction, perception and distribution cease to be determined and controlled by the civil order within the nation states. The expansion and legitimization of the space of open cultural pluralism does not remove, but exacerbates the question: to which community and in the name of what values should a person adapt to? Linguo-cultural splits occurred along the following lines of cultural interaction:

- ethnic, represents the relations between local ethnic groups, historicalethnographic, ethno-confessional social communities;

- national, based primarily on the dialogue of various state-political structures and political elites;

- civilizational, characterized by a meeting of fundamentally different types of sociality, value systems and forms of cultural creativity. In the everyday practice of cultural interaction, most often there are processes and relations characteristic of all the three levels of interaction.

\section{Conclusions}

Studying the intercultural interaction shifts in general, it should be noted that the role of the linguo-cultural component in the policy of intercultural communication has changed. The history of societies previously has had an infinite cultural diversity. But in previous eras, due to the difficulties of global communications, the attachment of a person's everyday life to one specific place, the linguistic and cultural identity was not felt sharply. A person then perceived linguo-cultural diversity through the prism of customary and relatively narrow national and civil patterns and norms that reduced or suppressed the open expression of cultural differences. At the present time, the issue of linguo-cultural self-determination is acquiring significant political acuteness in those countries whose culture has developed as a nationally homogeneous (at least normatively), though containing the whole cultural spaces that are not included in the dominant culture. 